
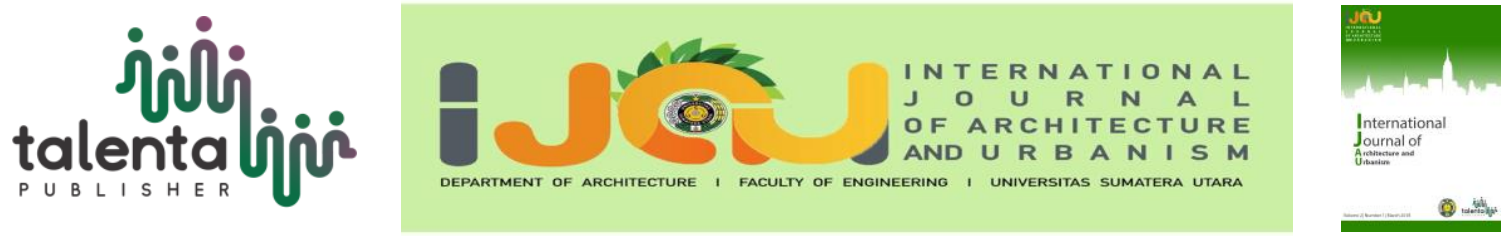

\title{
Market Relocation of Medan Labuhan
}

\author{
M. J. I. Nasution ${ }^{1 *}$, Nelson M Siahaan ${ }^{1}$ \\ ${ }^{1}$ Department of Architecture, Universitas Sumatera Utara, Medan, Indonesia
}

\begin{abstract}
With the needs of the growing community in the District of Medan Labuhan impact on improving people's living standards \& population growth. The increase is also in line with the growing demand of the provision of facilities and infrastructure because the higher the level of life of a person, the higher the demands on the provision of facilities, especially in service facilities and commerce. Therefore it is needed a container that can meet the needs of the place of shopping which is realized through "Market Relocation of Medan Labuhan" to buy and sell a place in Medan Labuhan. It aims to improve the economic level of the community in Medan Labuhan. With the formulation of the concept of traditional market orientation of the community as its users, it is expected to increase the attractiveness of the traditional market which can then increase the competitiveness between traditional markets and modern markets. The application of Neo Vernacular is aligned with the design of the building to achieve a balance between buildings, nature, and users.
\end{abstract}

Keyword: relocation, market, neo vernacular

\section{Introduction}

To improve the economic return of Medan Labuhan sub-district, there is a need for a place where the container can improve the regional economy and also can improve the image of this area in Medan Labuhan. One example is " Market Relocation of Medan Labuhan." The problems that exist in traditional markets, in general, are almost the same, namely the arrangement of the market that should be. As a result, not a few markets that survive and die, some can also survive but do not live optimally. An example is the Market of Medan Labuhan; traders are competing to choose to sell near the entrance area or on the road to make it easier to reach by buyers because buyers are also looking for a closer to the exit. As a result, there is a disadvantage that harms buyers and road users.

To keep this market can continue to have the appeal and survive with the growing market by modern, Pekong Market this port needs to be relocated and rebuilt with a physical arrangement

*Corresponding author at: Department of Architecture, Faculty of Engineering, Universitas Sumatera Utara,

Jalan Perpustakaan Gedung J07, Medan 20155, Indonesia

E-mail address: jefryirawan.nasution@gmail.com 
with the direction of physical arrangement that made need based on the requirement of society to be a more appropriate target.

\section{Literature Review}

The market in Indonesia has an important role as a place to find daily needs that are not produced by themselves. And also a place to improve the economy of people in the area. There are several definitions of the market. The first version states that the market is a place to sell and market goods or as a form of a shelter of trading activity [2]. The second version defines the market as where the buyer meets with the seller, where there are goods or services offered for sale and then the transfer of property [4]. Meanwhile, based on the Decree of the Minister of Industry and Trade No. 23 / MPP / Kep / 1/1998, the market is defined as a meeting place for sellers and buyers to carry out transactions in which the buying and selling process is formed.

\subsection{Object Description}

Pekong Labuhan Market Relocation is the design of Traditional Market which includes architectural design, structural design, circulation design, utility design, and development master plan based on function, shape, user activity, and related government regulation. This discussion is based on analyzes derived from literature studies and comparative studies.

\subsection{Design Location}

Location Pekan Labuhan General Hospital is in District of Medan-Labuhan. Medan-Labuhan Sub-district is one of the districts located in Medan City which has an area of about $36.67 \mathrm{~km} 2$ or $13.83 \%$ of the total area of Medan. The location of the design is on the road Yos Sudarso street Kecamatan Medan Labuhan Kelurahan Pekan Labuhan, which has a land area of 16,000 m2 (Figure 1).

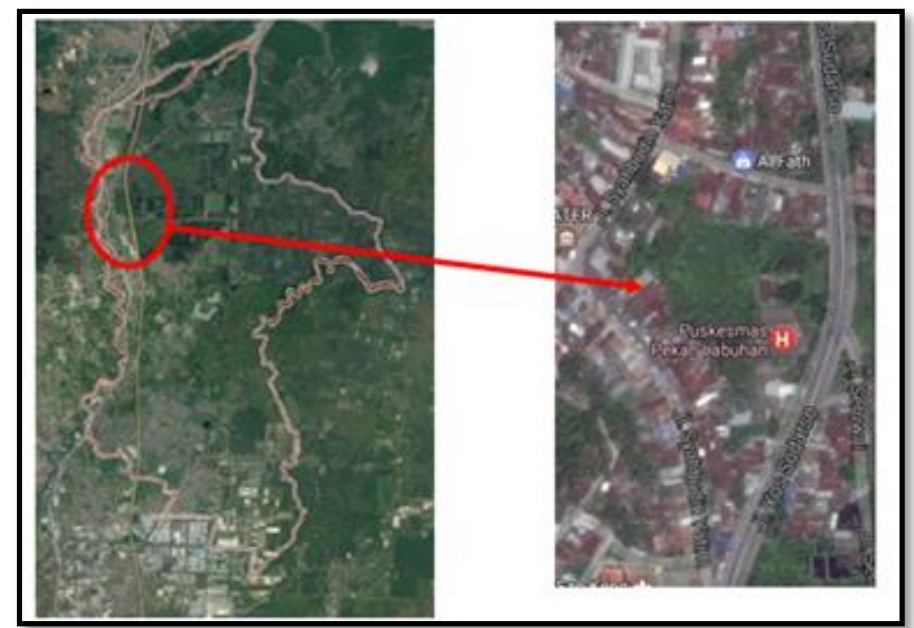

Figure 1. Location of Design 


\subsection{Theme}

Neo-Vernacular architecture grows from the customs of society and progresses through the configuration stage stages of various cultures so that it has external power. External power, among others, from Western industrial societies that spread the potential of modern technology with modern building materials. On the other hand, the community already has a strong regional cultural tradition that has been recognized by the community for decades. In this case, the location of the design is surrounded by historic areas that will be preserved sustainability. To convict the heritage region, the architecture in the embrace is colonial architecture. Neo vernacular architecture is applied with modern technology in the form of stell reinforcement on column and beams, on the door and window using aluminum and wood [1].

Colonial architecture is a short designation for architectural styles that developed during the Dutch occupation in the country. The entry of European elements into the population composition adds a wealth of architectural diversity in the archipelago. As the roles and powers grew, European camps became more dominant and permanent until they managed to expand and bring new typologies. The spirit of modernization and globalization (particularly in the 18th and 19th centuries) introduced modern buildings such as colonial administration, hospital or military facilities. These buildings are known as colonial buildings.

\section{Methodology}

The research design used in Market Relocation of Medan Labuhan is a qualitative research method, was research method used to examine the condition of a natural object, (as opposed to experimenting). The design site selection reference was based on the Building and Environmental Management Plan of Chinatown Medan Labuhan Area. Based on the Plan of Building and Environment, the designing location was intended for several functions, namely services and trade, transportation services, and health services.

\section{Result and Discussion}

\subsection{Basic Concept}

Neo-Vernacular architecture is an understanding of the flow of Post-Modern Architecture was born as a response and criticism of modernism that prioritizes the value of rationalism and functionalism that influenced the development of industrial technology. In the development of modern architecture, there is a form of form that refers to the local language by taking the elements of architecture that exist in the modern form [3]. Application of Neo Vernacular architectural concept in Pekong Labuhan Market building such as the utilization of building facade design by imitating colonial buildings around Medan Labuhan. 


\subsection{Zoning}

Location of design with an area of $\pm 16.000 \mathrm{~m} 2$ located on Yos Sudarso street Medan Labuhan has a GSB of $7 \mathrm{~m}$ from the main road. Site divided into several zoning that is mass of the main building, mechanical building with KDB $60 \%-80 \%$ or $\pm 10.000 \mathrm{~m} 2$ and green open space 15 $40 \%$ from land or $\pm 3.000 \mathrm{~m} 2$ (Figure 2 ).

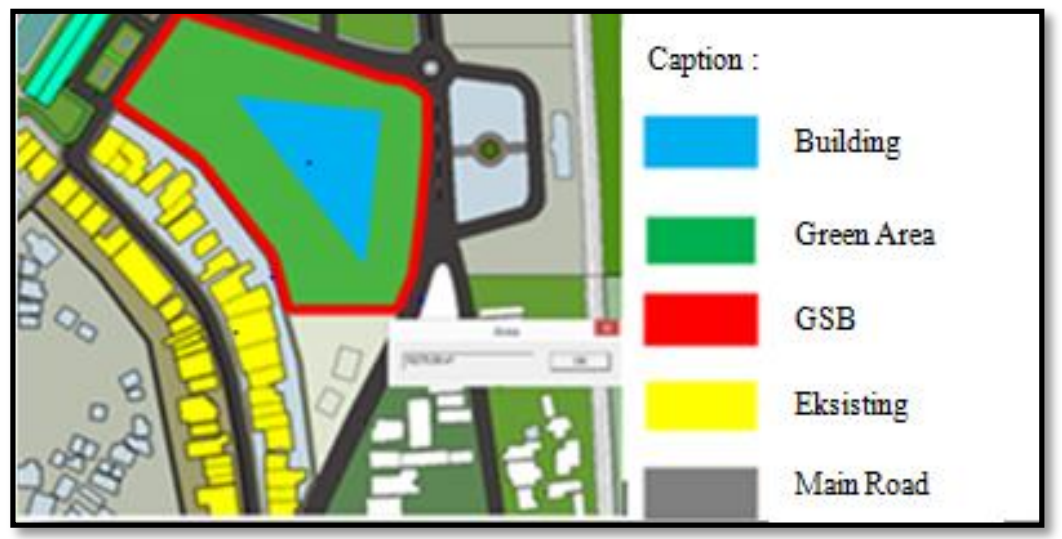

Figure 2. Zoning

\subsection{Outer Space}

Outside spatial arrangement on the site oriented to the processing of treads around the main mass that functioned as parking areas and parks. Parking Area Located on the site. This is because the parking needs Market that must be able to reach the entire site and facilitate visitors. At the entrance there are parks, drop off areas, and circulation in and out of vehicles (Figure 3).

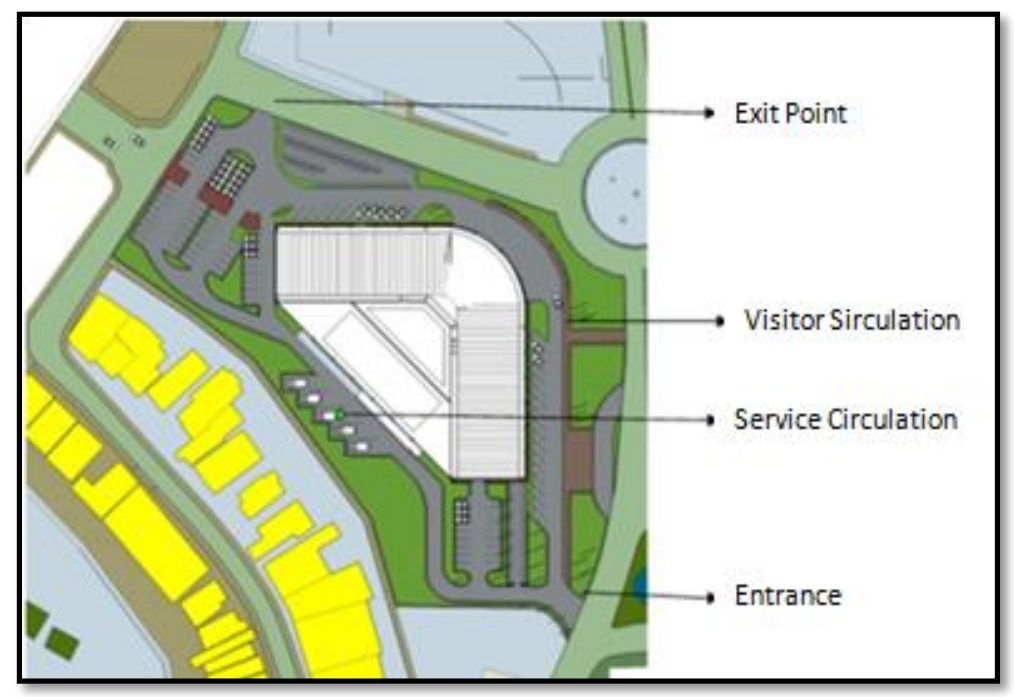

Figure 3. Outer Space

\subsection{Mass Changes}

The formation of building masses in Pekong Labuhan Market design is the formation of a triangle, where this formation can separate the zone zones that are not connected and facilitate service zone to reach all public zones to facilitate the circulation of the transfer of merchandise that will be sold on the market Pekong Labuhan (Figure 4). 


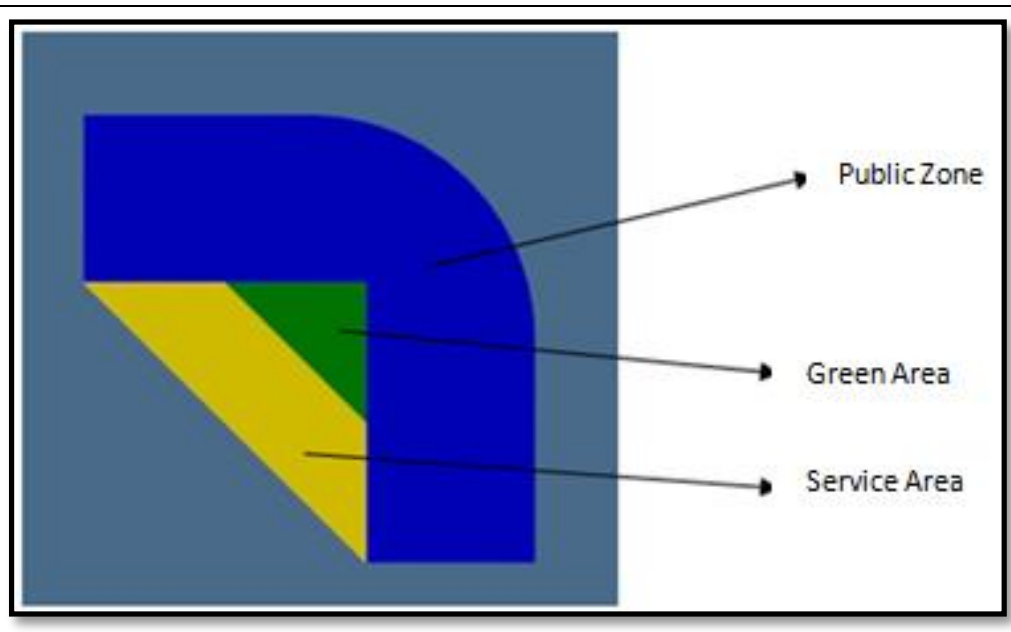

Figure 4. Zoning

\subsection{The Zone Floor Distribution}

The zoning on the 1st floor consists of two zones: public zone and service zone, where the public zone consists of loss, retail and cafe shop. And the service zone consists of a loading dock, Mechanical and Electrical room and warehouse. In the middle of the public zone and service zone, there is a green open space where it functions as a separator, maximizing circulation of buildings and air circulation in buildings (Figure 5).

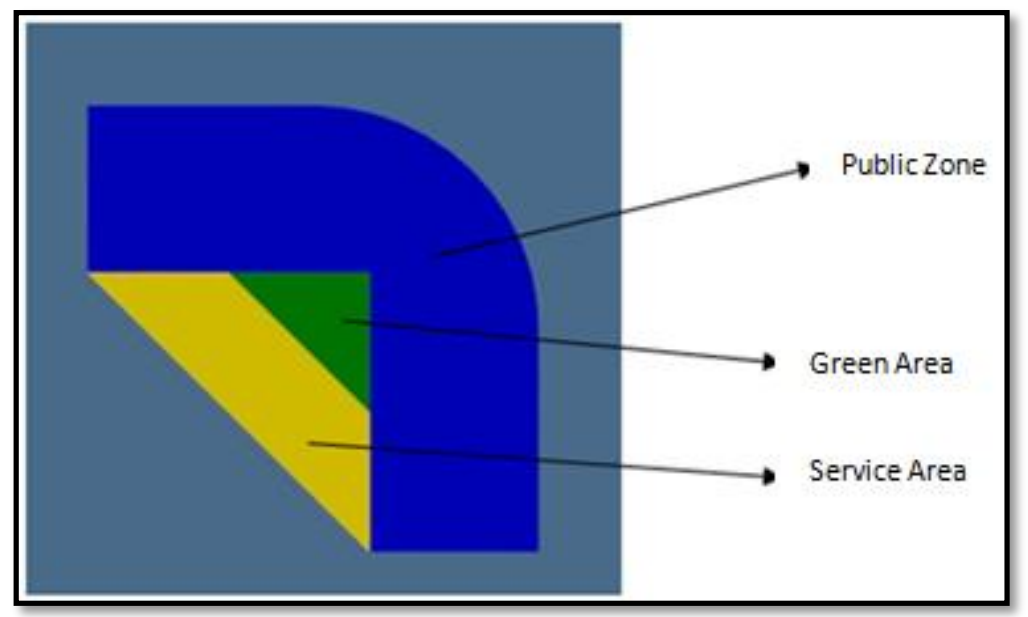

Figure 5. 1st Floor Zone

The zoning on the 2 nd floor consists of 3 zones: service zone, public zone, and semi-public. Where the service zone consists of warehouses, the semi-public zone consists of a training office, health room, common room, and Mushollah. And the public zone consists of loss, retail, and food court (Figure 6). 


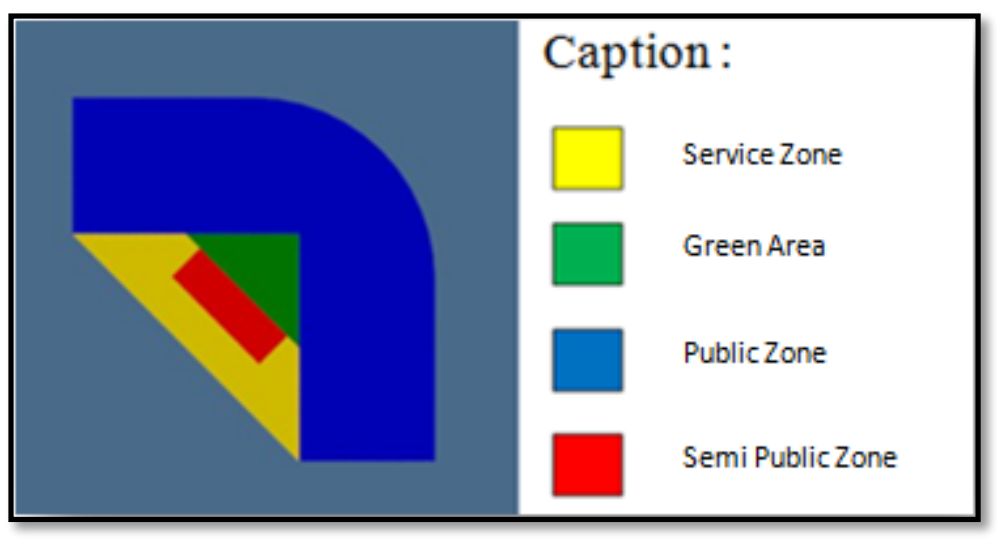

Figure 6. 2nd Floor Zone

\subsection{Structure Design}

The structural system used in the design of the Traditional Market is the rigid frame system structure, where the structure focuses more on the grid system that supports the function of the spaces within it. The combination of cores and columns forms a structure capable of supporting loads above it. And also use the structure, in general, such as; column, beam, beam ring and dilation. The main building column uses 80 × 80 columns. The building uses a boor pile foundation (Figure 7).

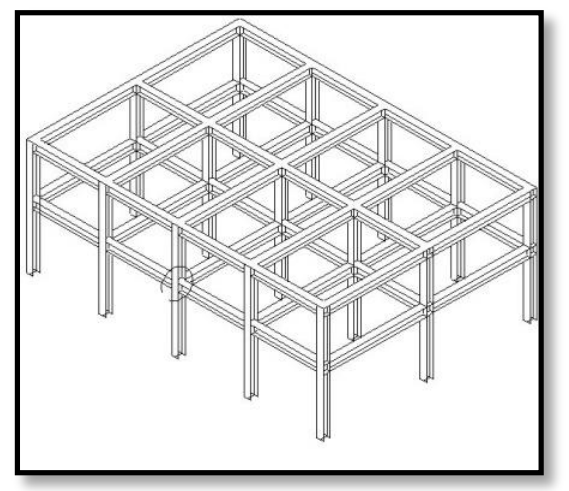

Figure 7. Rigid Frame Structure

\subsection{Exterior}

The Pekong Labuhan market is located on Yos Sudarso Street, Medan Labuhan Sub-district Medan. North Sumatra. This location is very strategic where the location is on the main road crossing Medan - Belawan. This makes this market very easy to travel with anyone and also many public transportations such as public transport and pedicab passing by on this street. This market is not like a traditional market in general in Indonesia, with modernly designed enables sellers and buyers convenient for use by all users.

In addition to traditional markets, there is also a shopping center as well as selling clothes, cloth, and other clothing needs. And also has supporting functions such as a cafe, foodcourt, retail and also a large parking area (Figure 8). 


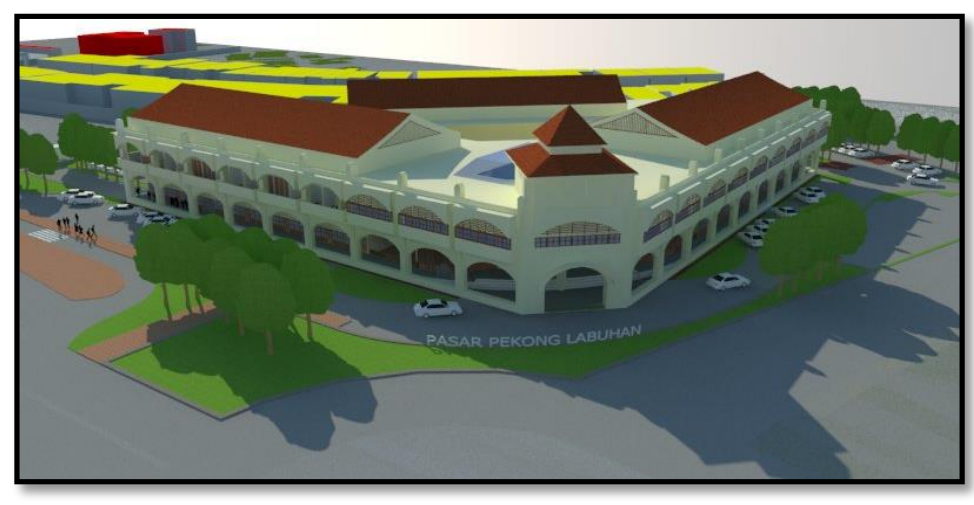

Figure 8. Market of Medan Labuhan

\section{Conclusion}

To improve the economic return of Medan Labuhan sub-district, there is a need for a place where the container can improve the regional economy and also can improve the image of this area in Medan Labuhan. One example is "Pekong Labuhan Market Area." With the formulation of the concept of a traditional market orientation of the community as its users, it is expected to increase the attractiveness of traditional markets which can then increase the competitiveness between traditional markets and modern markets. The application of Neo Vernacular is aligned with the design of the building to achieve a balance between buildings, nature, and users.

\section{Acknowledgment}

This research is part of the requirement to obtain a bachelor's degree in Architecture Departement Universitas Sumatera Utara.

\section{REFERENCES}

[1] D. Erdiono. Arsitektur 'Modren'(neo) Vernakuler di Indonesia. SABUA, 3(3). 2012.

[2] N. J. Ginanjar. Masalah Ekonomi Mikro. Jakarta: Acro. 1980.

[3] Haryadi \& A. Hatmoko. Buku Pegangan Kuliah Arsitektur Vernakular. Gadjah Mada University, Yogyakarta. 1999.

[4] W. J. Stanton. Prinsip Pemasaran. Jakarta: Erlangga. 1996. 